\title{
The use of moving bed bio-reactor to laundry wastewater treatment
}

\author{
Sławomira Bering ${ }^{1,{ }^{*}}$, Jacek Mazur ${ }^{1}$, Krzysztof Tarnowski ${ }^{1}$, Magdalena Janus ${ }^{1}$, Sylwia \\ Mozia $^{2}$, and Antoni Waldemar Morawski ${ }^{2}$ \\ ${ }^{1}$ West Pomeranian University of Technology, Szczecin, Faculty of Civil Engineering and \\ Architecture, al. Piastów 50, 70-311 Szczecin, Poland \\ ${ }^{2}$ West Pomeranian University of Technology, Szczecin, Institute of Chemical and Environment \\ Engineering, ul. Pułaskiego 10, 70-322 Szczecin, Poland
}

\begin{abstract}
Large laboratory scale biological treatment test of industrial real wastewater, generated in industrial big laundry, has been conducted in the period of May 2016-August 2016. The research aimed at selection of laundry wastewater treatment technology included tests of two-stage Moving Bed Bio Reactor (MBBR), with two reactors filled with carriers Kaldnes K5 (specific area $-800 \mathrm{~m}^{2} / \mathrm{m}^{3}$ ), have been realized in aerobic condition. Operating on site, in the laundry, reactors have been fed real wastewater from laundry retention tank. To the laundry wastewater, contained mainly surfactants and impurities originating from washed fabrics, a solution of urea to supplement nitrogen content and a solution of acid to correct $\mathrm{pH}$ have been added. Daily flow of raw wastewater Qd was equal to $0.6-0.8 \mathrm{~m}^{3} / \mathrm{d}$. The values of determined wastewater quality indicators showed that substantial decrease of pollutants content have been reached: $\mathrm{BOD}_{5}$ by $94.7-98.1 \%$, COD by $86.9-93.5 \%$, the sum of anionic and nonionic surfactants by $98.7-99.8 \%$. The quality of the purified wastewater, after star-up period, meets the legal requirements regarding the standards for wastewater discharged to the environment.
\end{abstract}

\section{Introduction}

Rising prices of water taking and wastewater discharging force industry to improve their water and wastewater management. Studies aimed at selection of laundry wastewater biological treatment technology for the large industrial laundry Albatros (Fliegel Textilservice group), localized nearby Szczecin city, have been undertaken. Project was conducted onsite and real laundry wastewater has been used. Currently Albatros laundry generates ca. $600 \mathrm{~m}^{3} / \mathrm{d}$ of wastewater average daily however maximum daily flow may reach the level of $800 \mathrm{~m}^{3} / \mathrm{d}$.

The quality of laundry wastewater depends on the types of washed materials. Generally wastewater contains dissolved and solid impurities washed from processed fabric as well as washing agents $[1,2]$.

\footnotetext{
*Corresponding author: slawomira.bering@zut.edu.pl
} 
Among, proposed in the subject literature, methods of treatment of wastewater containing surfactants, physicochemical, chemical (mainly oxidation), biological aerobic and anaerobic [3] as well as combined methods are indicated as effective for laundry wastewater treatment. A number of authors tested also membrane purification of laundry wastewater. Positive effects has been reached by coagulation followed by membrane ultrafiltration [4, 5]. Pre-precipitation gives effective charge neutralization, decreased fouling and increased critical flux [5]. Coagulation has also been used as stand-alone process of laundry wastewater treatment [6]. Electrocoagulation and electroflotation processes were effective in COD removal with efficiency on the level of $62 \%$. For Fenton process the reductions of COD and TOC were $85 \%$ and $69 \%$ [8]. The removal of the organic compounds was mainly carried out by Fenton-based $\mathrm{Fe}^{3+}$ coagulation rather than Fenton oxidation [8].

The total content of surfactants on the level below $2 \mathrm{mg} / \mathrm{L}$, in the outflow wastewater, has been reached by method based on preliminary coagulation then by flotation (DAF) followed by sand filtration, ozonation and eventually Granulated Activated Carbon (GAC) filtration [9].

Biological methods are also used for laundry wastewater treatment. These methods, similar to the coagulation, generates significant amounts of sludge however biological excess sludge could be used for the land reclamation which is an advantage of biological methods [10]. In the processes of anaerobic wastewater treatment by expanded granular sludge bed (EGSB) reactor [11, 12] and up-flow anaerobic sludge blanket reactor [13] the efficiency of removal of anionic surfactants was on the level of 76\% [11] and 78\% [13]. Membrane bioreactors (MBR), moving bed bioreactors (MBBR) as well as sequencing batch reactors (SBR) have been used for aerobic laundry wastewater treatment. Pilot MBR plant with microfiltration membrane reduce the COD of raw laundry wastewater by around 90\%. [14]. Part of the MBR permeate was subsequently treated by reverse osmosis (RO) filtration [14]. Results of MBBR test showed the possibility of reducing BOD to $12.7 \mathrm{mg} / \mathrm{L}$ and TOC to $6.8 \mathrm{mg} / \mathrm{L}$ [15]. In laboratory test of SBR COD at the outlet was not higher than $184 \mathrm{mg} \mathrm{O}_{2} / \mathrm{L}$ and COD removal efficiency was equal to $82-91 \%$ [1].

Laundry wastewater treated in MBBR were further successfully purified by membrane and advanced oxidation water renovation processes [16].

The aim of undertaken research was testing of the efficiency of moving bed bioreactor (MBBR) technology with Kaldnes K5 carriers in Albatros laundry wastewater treatment. Research has been conducted onsite in real conditions with usage of real raw wastewater discharged from the laundry.

\section{Materials and methods}

Large laboratory-scale moving bed bio reactor (MBBR) has been installed onsite in the large industrial laundry Albatros (Fliegel Textilservice group), localized nearby Szczecin city. The real, mechanically pretreated, wastewater was pumped continuously to MBBR.

Studies have been done during the period from May to August 2016.

\subsection{Materials and equipment}

The laundry wastewater, contained mainly surfactants and impurities originating from washed fabrics. The Albatros laundry mostly washing linens from high standard hotels and wastewater contains mainly chemicals used for wet washing and impurities removed from linens. Composition of washing agents used in the laundry was analyzed. Used surfactants fulfill biodegradation criteria described in the regulation (EC) No 648/2004 of the European 
Parliament and the Council of 31 March 2004 on detergents. Dozing of detergents is automated. The raw wastewater used for research has been taken from the $350 \mathrm{~m}^{3}$ capacity equalization tank in which wastewater from wet washing processes and from regeneration of ion exchange columns, used for water softening, is collected. In the equalization tank heat is recovered and wastewater is cooled down to the temperature of ca. $40^{\circ} \mathrm{C}$.

To improve conditions of biological treatment the water solution of urea, as nitrogen source, has been dozed (20 mg per $1 \mathrm{~L}$ of wastewater) to the raw wastewater. Phosphorus has not been added. Based on $\mathrm{pH}$ measurements in the first MBBR tank sulphuric acid water solution $\left(\mathrm{H}_{2} \mathrm{SO}_{4}\right.$ ca. $10 \%$ ) has been used for automated $\mathrm{pH}$ control (above $\mathrm{pH} 8$ ).

The research included tests of two-stage moving bed bio reactor (MBBR), with two reactors filled with carriers Kaldnes K5 (specific area $-800 \mathrm{~m}^{2} / \mathrm{m}^{3}$ ) and total capacity equal to $400 \mathrm{dm}^{3}$, have been realized in aerobic condition with coarse bubble aeration system. The scheme of the tested wastewater treatment system is presented in Figure 1. Microorganisms, typical for active sludge and biological bed, grew on the Kaldnes K5 carriers (Figure 1) floating in the wastewater.

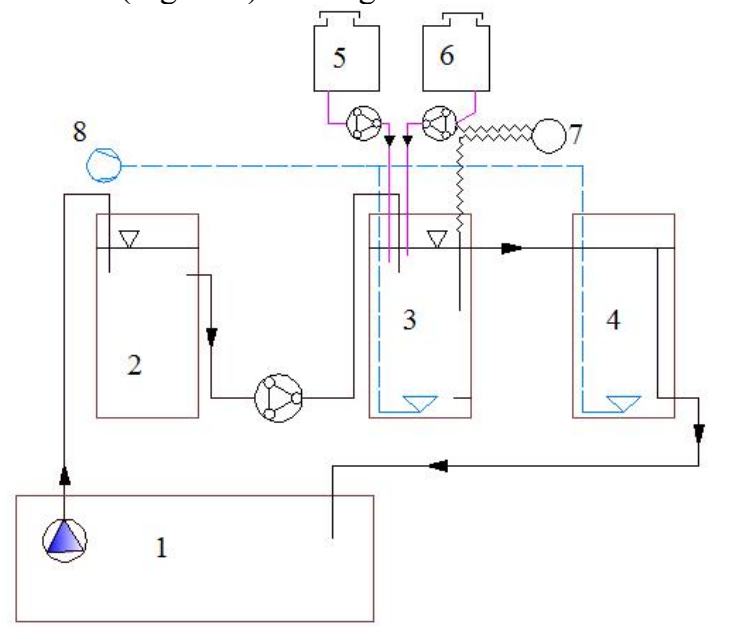

$$
\begin{aligned}
& 1 \text { - } 350 \text { m3 capacity equalization tank } \\
& 2 \text { - buffer tank } \\
& 3 \text { - reactor } M B B R \text { - } 1 \text { stage } \\
& 4 \text { - reactor } M B B R \text { - } 2 \text { stage } \\
& 5 \text { - urea pump } \\
& 6 \text { - acid pump } \\
& 7 \text { - pH measurment } \\
& 8 \text { - blower }
\end{aligned}
$$

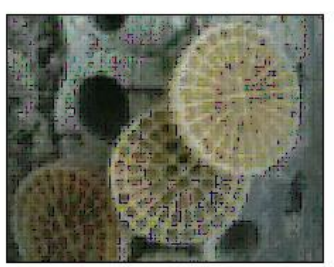

Fig. 1. The technological scheme of MBBR. The photograph of Kaldnes K5 carriers.

Start-up of MBBR has been conducted with wastewater daily flow Qd equal to $0.6 \mathrm{~m}^{3} / \mathrm{d}$ (mean hourly flow $\mathrm{Qh}=25 \mathrm{~L} / \mathrm{h}$ ) and, in the time of the tests, the daily flow equal to $0.8 \mathrm{~m}^{3} / \mathrm{d}$ (mean hourly flow $\mathrm{Qh}=33 \mathrm{~L} / \mathrm{h}$ ) has been reached. The source of activated sludge for inoculate of MBBR was communal wastewater treatment plant in Gryfino town. WWTP in Gryfino is recipient of the Albatros laundry wastewater which means that activated sludge is already adopted to that type of wastewater. Mixed liquor suspended solids (MLSS) in the taken, from a thickener, activated sludge was equal to ca. $15 \mathrm{~g} / \mathrm{L}$. Concentration of dissolved oxygen in MBBR tanks was maintained on the level of 2-4 mg $\mathrm{O}_{2} / \mathrm{L}$.

\subsection{Analytical methods}

Wastewater quality has been determined by:

- chemical oxygen demand (COD) according to the PN-ISO 6060:2006,

- 5-day biochemical oxygen demand $\left(\mathrm{BOD}_{5}\right)$ according to the ISO 15705:2002,

- total nitrogen according to the PN-EN 25663 and LCK 238 cuvette tests (Hach-Lange),

- nitrate nitrogen by Spectroquant 14773 test (Merck),

- total phosphorus according to the EN ISO 6878 and LCK 350 cuvette tests (Hach-Lange), 
- anionic and non-ionic surfactants according to the PN-EN 903 and PN-ISO 7875-2 as well as by LCK 332 and LCK 333 cuvette tests (Hach-Lange),

- total suspended solids TSS/mixed liquor suspended solids MLSS by gravimetric method,

- chlorides according to the PN-ISO 9297:1994,

- $\mathrm{pH}$ and conductivity ( $\mathrm{pH} / \mathrm{EC} / \mathrm{T}$ CPC-505 laboratory $\mathrm{pH} /$ conductivity meter).

For checking the stable operation of the wastewater treatment system, in the time of MBBR working parameters changes (e.g. start-up, change in wastewater flow), only COD or BOD and COD has been determined (11 follow-up and 10 monitoring samples 21 samples in total).

\section{Discussion of results}

Tests of laundry wastewater treatment efficiency using MBBR technology were included in the study. The quality of the laundry raw wastewater was determined and wastewater treatment test was conducted.

\subsection{Raw wastewater quality}

The values of determined raw wastewater quality indicators are presented in the Table 1.

Table 1. Quality of mechanically treated Albatros laundry raw wastewater (sampling 05-08.2016).

\begin{tabular}{|c|c|c|c|c|c|}
\hline & \multirow{2}{*}{ Parameter/Indicator } & \multirow{2}{*}{ Unit } & \multirow{2}{*}{$\begin{array}{c}\text { Allowable } \\
\text { limit }\end{array}$} & \multicolumn{2}{|c|}{ Value } \\
\hline & & & & Max. & Min. \\
\hline 1 & $\mathrm{pH}$ & & $6.5-9.5$ & 8.5 & 7.7 \\
\hline 2 & COD & $\mathrm{mg} \mathrm{O}_{2} / \mathrm{L}$ & 125 & 1087 & 479 \\
\hline 3 & $\mathrm{BOD}_{5}$ & $\mathrm{mg} \mathrm{O}_{2} / \mathrm{L}$ & 25 & 538 & 271 \\
\hline 4 & $\begin{array}{c}\text { Total Suspended Solids } \\
\text { TSS }\end{array}$ & $\mathrm{mg} / \mathrm{L}$ & 35 & 191 & 104 \\
\hline 5 & conductivity & $\mu \mathrm{S} / \mathrm{cm}$ & & 3085 & 1800 \\
\hline 6 & Chlorides & $\mathrm{mg} / \mathrm{L}$ & 1000 & 642 & 225 \\
\hline 7 & Total phosphorus & $\mathrm{mg} \mathrm{P} / \mathrm{L}$ & 2 & 6.73 & 2.45 \\
\hline 8 & Total Nitrogen & $\mathrm{mg} \mathrm{N} / \mathrm{L}$ & 30 & 13.11 & 9.64 \\
\hline 9 & $\begin{array}{c}\text { Anionic Surfactants } \\
\text { (MBAS) }\end{array}$ & $\mathrm{mg} / \mathrm{L}$ & 5 & $\begin{array}{c}9.2^{* *} \\
26.1 * * * \\
\end{array}$ & $\begin{aligned} 5.56^{* *} \\
17.4^{* * *}\end{aligned}$ \\
\hline 10 & $\begin{array}{c}\text { Nonionic Surfactants } \\
(\mathrm{BiAS})\end{array}$ & $\mathrm{mg} / \mathrm{L}$ & 10 & $\begin{array}{c}69.9 * * \\
74.2^{* * *}\end{array}$ & $\begin{array}{c}38,2 \\
31.6^{* * * *}\end{array}$ \\
\hline
\end{tabular}

**result according to the standards methods of surfactants determination (anionic surfactants PNEN 903 - determination of anionic surfactants by measurement of the methylene blue index MBAS; PN-ISO 7875-2 - determination of non-ionic surfactants using Dragendorff reagent) [17]; ***results according to the cuvette tests (LCK 332 for anionic surfactants and LCK 333 for nonionic) [17]

Characteristic for the investigated laundry raw wastewater, in comparison to communal sewage, are high content of surfactants (anionic and nonionic), low content of total nitrogen and slightly elevated level of phosphorus. Periodically high concentration of chlorides have been also observed.

Differences in the results of anionic and nonionic determination between standard and cuvette tests methods are also confirmed by previous research [17]. Variability in the total phosphorus concentration is most likely caused by a occasional use of washing agents with increased content of phosphates 
The quality of raw wastewater has been determined. Ratio of chemical oxygen demand (COD) to five day biochemical oxygen demand $\left(\mathrm{BOD}_{5}\right)$, in the period of conducted research, varied in the range of 1.6 to 2.09. The amounts of, necessary for proper wastewater biological treatment, nutrients have been also determined. The ratio of five day biochemical oxygen demand to total nitrogen and total phosphorus $\mathrm{BOD}_{5} / \mathrm{N} / \mathrm{P}$ has been calculated. Given in the literature value of that ratio, for proper wastewater biological treatment, is equal to $100 / 5 / 1$ [18]. The median of the $\mathrm{BOD}_{5} / \mathrm{N} / \mathrm{P}$ ratio, calculated based on the results of quality determination of ten wastewater samples, was equal to 100/2.97/1.25 which indicated that there is deficiency of nitrogen and periodical deficiency of phosphorus in the laundry wastewater. The amount of phosphorus in raw wastewater related to the amount of 100 units of $\mathrm{BOD}_{5}$ varied in the range of $2.15-0.68$. Value below one have been recorded in three samples.

\section{2. Laundry wastewawater treatment efficiency tests}

After five weeks MBBR start-up the permanent reduction of $\mathrm{COD}$ and $\mathrm{BOD}_{5}$ values have been reached. Obtained $\mathrm{COD}$ and $\mathrm{BOD}_{5}$ values were below the allowable limits given in the appendix no 4 of Regulation of the Minister of Environment of 18 November 2014 establishing conditions to be met for wastewater discharged into water or ground (...) [19]. The allowable limits are equal to $125 \mathrm{mg} \mathrm{O} / \mathrm{L}$ for $\mathrm{COD}$ and $25 \mathrm{mg} \mathrm{O}_{2} / \mathrm{L}$ for $\mathrm{BOD}_{5}$. Obtained results of $\mathrm{COD}$ and $\mathrm{BOD}_{5}$ treated wastewater determination, in relation to the allowable limits, are presented in figures no $2(\mathrm{COD})$ and $3\left(\mathrm{BOD}_{5}\right)$.

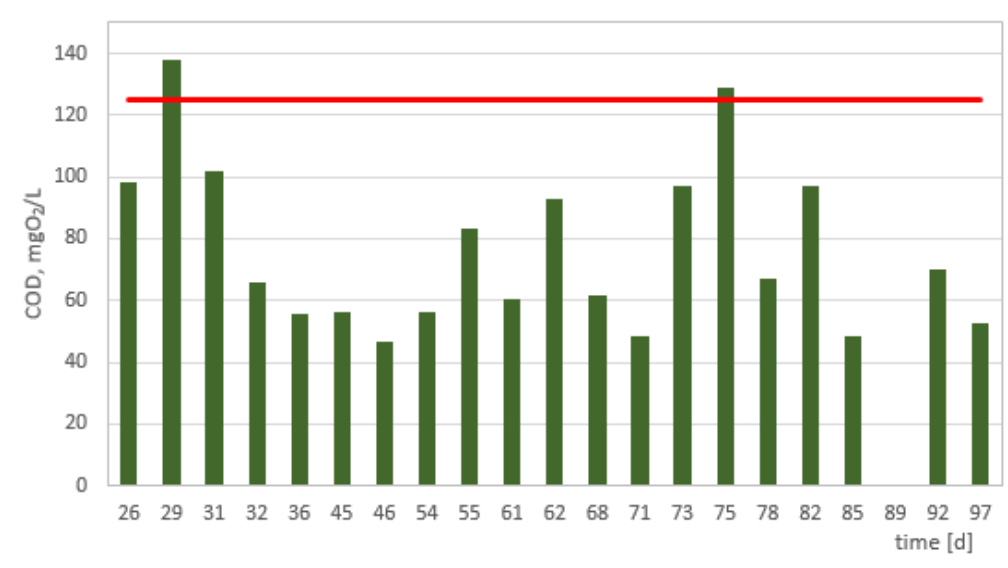

Fig. 2. $\mathrm{COD}$ in treated wastewater. 1 results of $\mathrm{COD},-\mathrm{COD}$ allowable limit. 


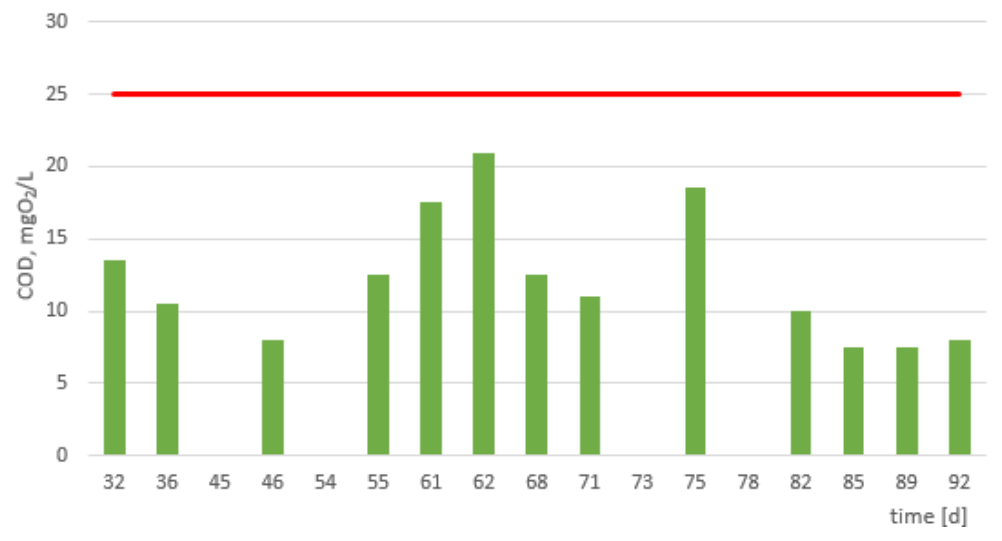

Fig. 3. $\mathrm{BOD}_{5}$ in treated wastewater. $\square$ results of $\mathrm{BOD},-\mathrm{BOD}$ allowable limit.

Determined values of $\mathrm{BOD}_{5}$ indicator for treated wastewater, for MBBR stable operation periods, reached the values of $7.5-17.5 \mathrm{mg} \mathrm{O} / \mathrm{L}$ while COD values varied in the range from 46.7 to $102.0 \mathrm{mg} \mathrm{O}_{2} / \mathrm{L}$. Exceeding of allowable COD value has been observed in the start-up period and in emergency situation caused by raw wastewater feeding pump failure ( $75^{\text {th }}$ day). Short increase of COD value has been noticed after wastewater flow increase ( $62^{\text {th }}$ day) however allowable value has not been exceeded. In the period of stable operation the MBBR treatment efficiency, defined as ratio of removed pollution load to inflowing pollution load, was equal to $94.7-98.1 \%$ for $\mathrm{BOD}_{5}$ and $86.9-93.5 \%$ for COD. Efficiency of $\mathrm{BOD}_{5}$ and $\mathrm{COD}$ removal is presented in figure 4.

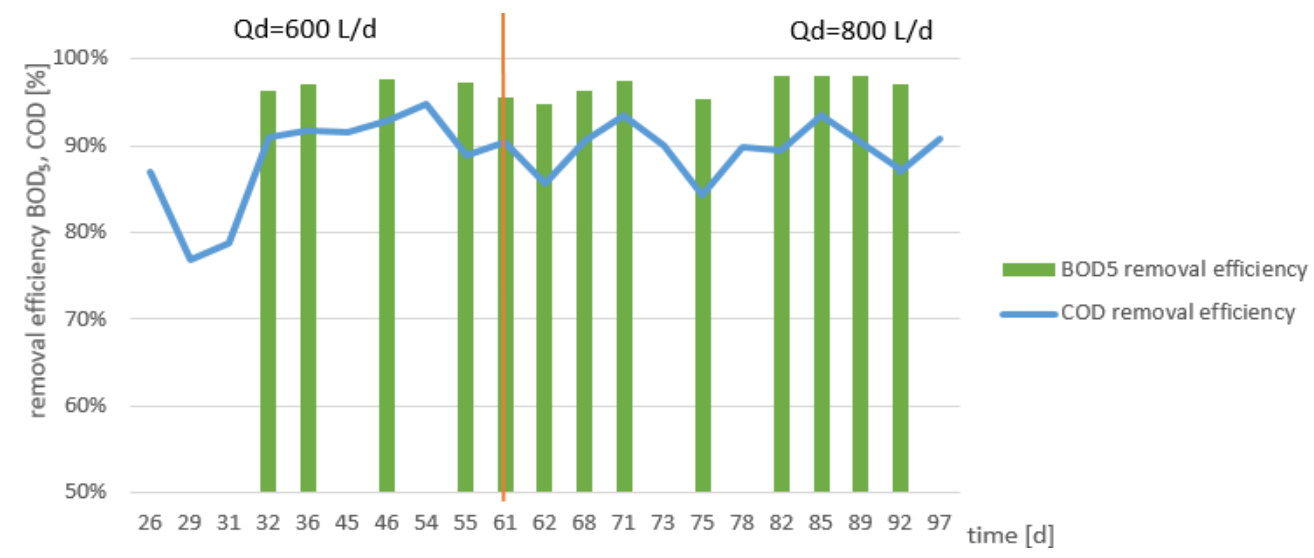

Fig. 4. $\mathrm{COD}$ removal efficiency and $\mathrm{BOD}_{5}$ removal efficiency of laundry wastewater.

Removal efficiency on the level of $90 \%$ noticed in three successive measurements has been assumed as indicator of MBBR stable operation. Initial, lower COD removal efficiency shows the start-up period. Removal efficiency on the level of $90 \%$ has been reached in $32^{\text {rd }}$ day of experiment. That result has been confirmed in the two next samples. After increasing of raw wastewater flow (in $62^{\text {rd }}$ day) and consequently higher biological bed loading, the short decreasing of treatment efficiency has been observed. For the flow equal to $0.8 \mathrm{~m}^{3} / \mathrm{d}$ stabilization in the treatment efficiency, on the level of $90 \%$, has been reached after 10 days. Breakdown of the process, observed in day 75, can be explained by raw wastewater feeding pump failure. For 1 day there was no wastewater inflow, but aeration system and dosing systems have been working. Three days after emergency 
efficiency return to the level under $90 \%$ which shows relative flexibility of biological system for accommodation to rapid changes in real wastewater flow.

The variability in efficiency of $\mathrm{BOD}_{5}$ removal in relation to the changes in biological bed active surface loading has been calculated (figure 5).

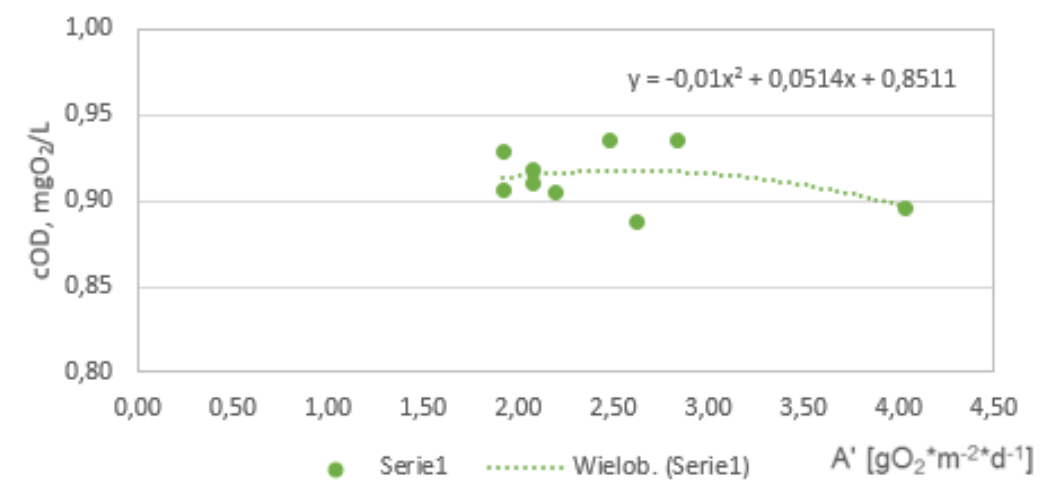

Fig. 5. BOD 5 removal efficiency versus biological bed active surface loading (A').

Loading $\left.\mathrm{A}^{\prime}\left[\mathrm{gO}_{2} \cdot \mathrm{m}^{-2} \cdot \mathrm{d}^{-1}\right)\right]$ has been calculated based on the formula given below [20]:

$$
A^{\prime}=L_{B O D} / F_{a}
$$

where: $L_{B O D}-\mathrm{BOD}_{5}$ load in the raw wastewater inflowing to the MBBR $[\mathrm{g} / \mathrm{d}] ; F_{a}-$ active surface of biological bed.

$$
F_{a}=F_{s} \cdot V_{B B} \cdot V_{\%}
$$

where: $F_{s}$ - specific area of carriers, for Kaldnes $\mathrm{K} 5 F_{s}=800 \mathrm{~m}^{2} / \mathrm{m}^{3} ; V_{B B}$ - capacity of MBBR tanks, $V_{B B}=0.400 \mathrm{~m}^{3} ; V_{\%}$ - filling degree of tanks by Kaldnes carriers, $n=0.33$. Calculated active surface $\mathrm{F}_{\mathrm{a}}$ is equal to $107 \mathrm{~m}^{2}$.

The quadratic polynomial trendline (correlation coefficient $\mathrm{R}^{2}=0.153$ ) for BOD removal efficiency versus biological bed active surface loading is shown in the figure 5 . The decrease of removal efficiency with increase of biological bed active surface loading is visible. It can be assumed that in the range of tested loading $\left(1.9-4 \mathrm{~g} \mathrm{O}_{2} \cdot \mathrm{m}^{-2} \cdot \mathrm{d}^{-1}\right)$ biological bed operated with expected organic pollutants removal efficiency. Because of low levels of ammonia, nitrate and total nitrogen nitrification process has not been used.

Concentration of total phosphorus in raw and treated wastewater is shown in figure 6.

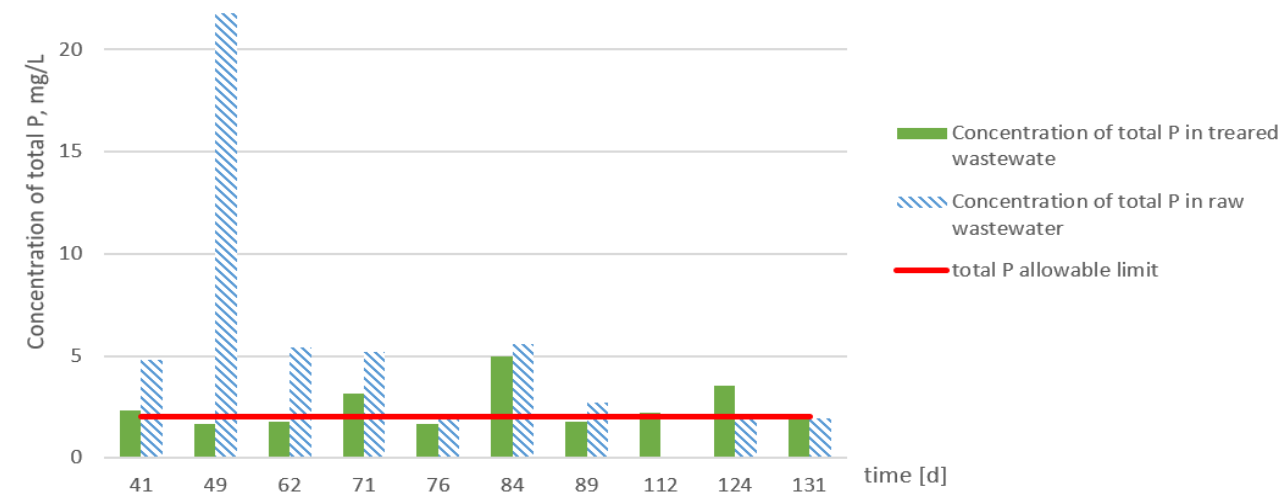

Fig. 6. Concentration of total phosphorus $P$ in raw and treated wastewater. 
Content of the total phosphorus in the raw laundry wastewater varied however most frequently it concentration was only slightly above the allowable limit. Treatment processes, conducted in aerobic conditions, not always allowed to reduce total phosphorus content to the level below allowable limit. In raw wastewater, in 3 samples (in $46^{\text {th }}, 54^{\text {th }}$, $89^{\text {th }}$ days), ratio $\mathrm{BZT}_{5} / \mathrm{P}$ was lower than 1 which means that significant deficit of phosphorus took place [18] however, as it is shown in figure 4, substantial decrease in removal efficiency of $\mathrm{BOD}_{5}$ and $\mathrm{COD}$ has not been observed despite of flow raising and emergency brake in power delivery. Biological bed's microorganisms had assured, constant delivery of raw wastewater with stable composition and optimal for them temperature $\left(25-35^{\circ} \mathrm{C}\right)$ which can reduce demand for a phosphorus compounds. At the same time weak excess sludge sedimentation ability has been observed [21].

The surfactants removal efficiency was equal to $98.7-99.7 \%$ for anionic, $98.6-99.8 \%$ for nonionic ones and $98.7-99.8 \%$ for the sum of anionic and nonionic surfactants.

\section{Conclusions}

1) Application of Moving Bed Bio Reactor technology for Albatros laundry wastewater treatment gives the good results. The quality of treated wastewater is in accordance with the regulation establishing conditions to be met for wastewater discharged into water or ground [19]. Removal of nitrogen is not required.

2) Removal efficiency of organic pollutants, determined as $\mathrm{BOD}_{5}$ and $\mathrm{COD}$, is equal to 94.7-98.1\% for $\mathrm{BOD}_{5}$ and 86.9-943.5 for COD.

3) Deficit of nitrogen in raw wastewater means necessity of nitrogen nutrient dozing.

4) In the range of tested biological bed active surface loading $\left(1.9-4 \mathrm{~g} \cdot \mathrm{m}^{-2} \cdot \mathrm{d}^{-1}\right)$ biological bed operated with $\mathrm{BOD}_{5}$ removal efficiency on the level of $94.7-98.1 \%$.

5) Content of the total phosphorus in the raw laundry wastewater varies and periodically a deficit of phosphorus, in relation to removed BOD5 load, is observed. In aerobic biological treatment of investigated laundry wastewater, elevated up to ca. $5 \mathrm{mg} / \mathrm{L}$, content of phosphorus cannot be reduced down to the allowable limit according to the regulation establishing conditions to be met by wastewater discharged into water or ground.

6) Observed deficit of phosphorus does not affect the efficiency of $\mathrm{BOD}_{5}$ removal.

The research was financed by The National Centre for Research and Development in Poland within the Applied Research Programme (project No. PBS2/B9/23/2013).

\section{References}

1. J. Podedworna, M. Żebrowska-Sudoł, Gaz, Woda i Technika Sanitarna 4, 21 (2007)

2. S. Bering, J. Mazur, K. Tarnowski, Civil and Environ. Eng. Rep. 6, 33 (2011)

3. K. Jardak, P. Drogui, R. Daghrir, Environ. Sci. Pollut. Res. 23, 3 (2016)

4. H-C. Kim, X. Shang, J.H. Huang, B.A. Dempsey, J. Membrane. Sci. 456, 167 (2014)

5. X. Shang, H-C Kim, J.H. Huang, B.A. Dempsey, Sep. Purif. Technol. 147, 44 (2015)

6. E.A.M. Ribeiro, F.R.B. De Souza, F.A., G.R. Do Amaral, G.R. Filho, R.M.F De Sousa, J.G. Vieira, T.F. De Rezende Costa, J.P. Thompson, R.M.N. De Assunção, S.C. Canobre, Quim. Nova 40, 1 (2017)

7. C-T. Wang, W-L. Chou, Y-M. Kuo, J. Hazard. Mater. 164, 81 (2009) 
8. M. Vilve, A. Hirvonen, M. Sillanpää, J. Hazard. Mater. 164, 1468 (2009)

9. I. Ciabattia, F. Cesarob, L. Farallia, E. Fatarellaa, F. Tognottia, Desalination 245, 451 (2009)

10. K. Tarnowski, S. Bering, A. Iżewska, Mazur J. Przem. Chem. 95, 8 (2016)

11. T.P. Delforno, A.G.L. Moura, D.Y. Okada, M.B.A. Varesche, Bioresource Technol. 154, 114 (2014)

12. T.P. Delforno, A.G.L. Moura, D.Y. Okada, I.K. Sakamoto, M.B.A. Varesche, Bioresource Technol. 192, 37-45 (2015)

13. D.Y. Okadaa, T.P. Delfornoa, A.S. Estevesa, I.K. Sakamotoa, I.C.S. Duarteb, M.B.A. Vareschea, Bioresource Technol. 128, 1 (2013)

14. J. Hoinkis, V. Panten, Chem. Eng. Process 47, 1159 (2008)

15. B. Altenbaher, M. Levstek, B. Neral, S.Š. Turk, Tekstil 59, 340 (2010)

16. S. Mozia, M. Janus, P. Brożek, S. Bering, K. Tarnowski, J. Mazur, A.W. Morawski, Environ. Sci. Pollut. R. 23, 19 (2016)

17. J. Mazur, S. Bering, K. Tarnowski, Przem. Chem. 95, 8 (2016)

18. Z. Sadecka, Podstawy biologicznego oczyszczania ścieków (Seidel - Przywecki, 2010)

19. Regulation of the Minister of Environment of 18 November 2014 establishing conditions to be met for wastewater discharged into water or ground and on substances particularly harmful to the aquatic environment. (Journal of Laws of 2006, no. 1800)

20. ATV A 135 guideline

21. Y. Azimi, D.G. Allen, P. Seto, R. Farnood, Ind. Eng. Chem. Res. 53, 31 (2014) 